\title{
Effects of captopril (SQ 14,225) in a patient with primary pulmonary hypertension
}

\author{
J. D. HOROWITZ \\ M.B. B.S., F.R.A.C.P. \\ J. B. BRENNAN \\ M.B. B.S., F.R.A.C.P. \\ L. E. Oliver \\ M.B. B.S., F.R.A.C.P. \\ D. HARDING \\ M.B. B.S., F.R.C.P., F.R.A.C.P. \\ A. J. Goble \\ M.D., F.R.C.P., F.R.A.C.P. \\ W. J. LouIS \\ M.B. B.S., F.R.A.C.P.

\begin{abstract}
Departments of Cardiology, Medicine and Clinical Pharmacology, Austin Hospital, Melbourne
\end{abstract}

\begin{abstract}
Summary
In a 33-year-old patient with severe primary pulmonary hypertension, the acute administration of the angiotensin-converting-enzyme inhibitor captopril (SQ $14,225)$ induced a rise in cardiac output, and a fall in both pulmonary and systemic vascular resistance. Subsequent chronic oral administration of captopril induced only transient clinical improvement, and the patient died. Captopril may nevertheless be useful in the treatment of less advanced cases of this disease.
\end{abstract}

\section{Case report}

A 33-year-old married woman with 2 children was admitted to hospital in February, 1979 for management of right heart failure due to primary pulmonary hypertension. There was a past history of Raynaud's phenomenon and mild systemic hypertension. Oral contraceptives had last been used 18 months previously.

Exertional dyspnoea had been present for 15 months. Physical examination revealed signs of severe pulmonary hypertension with no evidence of intracardiac shunt. Pulmonary arteriography in September 1978 revealed no evidence of embolic disease. The pulmonary artery pressure was 70/32 $\mathrm{mmHg}$ (mean $50 \mathrm{~mm}$ ). Pulmonary artery saturation was $53 \%$.

The patient's course between April 1978 and February 1979 was marked by gradual clinical deterioration with incapacitating dyspnoea on minimal exertion and stress.

Address for reprints: Professor W. J. Louis, Department of Clinical Pharmacology, Austin Hospital, Heidelberg, 3084. Vic. Australia.
On examination in February 1979 she was dyspnoeic at rest, with central cyanosis. Systemic BP was $80 / 50 \mathrm{mmHg}$, and the jugular venous pressure was elevated $15 \mathrm{~cm}$. There was poor peripheral perfusion, with a prominent right ventricular impulse and a left parasternal fourth heart sound. Hepatomegaly, gross ascites, and peripheral oedema were present.

The patient was treated with bed rest, frusemide $(40 \mathrm{mg} /$ day) and amiloride ( $5 \mathrm{mg}$ twice/day). Chest $\mathrm{X}$-ray showed cardiomegaly with a large right ventricle and oligaemic lung fields. Haemoglobin was $14.9 \mathrm{~g} / \mathrm{dl}$ with normal white cell and platelet counts. Arterial blood gases (while breathing air) were $\mathrm{Po}_{2}, 35 ; \mathrm{PCO}_{2}, 34 ; \mathrm{pH} \mathrm{7.39}$.

In view of the patient's deteriorating clinical status, a trial of captopril (SQ 14,225) was arranged. Informed consent was obtained, and treatment with indomethacin $(125 \mathrm{mg} /$ day) was commenced before the initiation of treatment with captopril.

A Swan-Ganz thermodilution catheter was inserted for monitoring of the haemodynamic effects before and after the initial dose of captopril $(6 \mathrm{mg})$. These are summarized in Table 1 . Valid pulmonary wedge pressure tracings could not be obtained. The maximum increase in cardiac output occurred 1.25 $\mathrm{hr}$ after the administration of captopril and persisted for $2.5 \mathrm{hr}$. A subsequent dose of $12.5 \mathrm{mg}$ failed to produce a further response.

In view of the acute response to oral captopril, long-term treatment was commenced, in a dose of $12.5 \mathrm{mg} 8$-hourly. There was some reduction in dyspnoea at rest, and the patient became less cyanosed, with a concomitant improvement in hypoxaemia $\left(\mathrm{PO}_{2}, 53 ; \mathrm{PCO}_{2}, 34 ; \mathrm{pH}, 7.51\right.$ while 
TABLE 1. Haemodynamic response to initial $6 \mathrm{mg}$ oral dose of captopril (SQ 14,225)

\begin{tabular}{|c|c|c|}
\hline & $\begin{array}{c}\text { Before } \\
\text { captopril }\end{array}$ & $\begin{array}{c}\text { After } \\
\text { captopril }\end{array}$ \\
\hline Heart rate (beats/min) & 92 & 98 \\
\hline $\begin{array}{l}\text { Systemic blood pressure } \\
(\mathrm{mmHg})\end{array}$ & $82 / 55$ & $90 / 55$ \\
\hline Mean right atrial pressure & 37 & 36 \\
\hline Pulmonary arterial pressure & $95 / 42$ & $92 / 40$ \\
\hline $\begin{array}{l}\text { Pulmonary arterial pressure } \\
\text { (mean) }\end{array}$ & 59 & 57 \\
\hline Cardiac output (1/min) & $1 \cdot 78$ & $3 \cdot 04$ \\
\hline $\begin{array}{l}\text { Systemic vascular resistance } \\
(\text { dyn-sec-cm }\end{array}$ & 2650 & 1500 \\
\hline $\begin{array}{l}\text { Pulmonary vascular resistance } \\
\left(\text { dyn-sec-cm }{ }^{-5}\right)\end{array}$ & e 1210 & 820 \\
\hline
\end{tabular}

breathing air). However, gross right heart failure persisted in spite of continued use of diuretics.

After captopril had been used for 16 days, a decision was made to stop all active treatment because of the patient's continued gross disability.

Thereafter, clinical deterioration was rapid, with falling urine output and reduced peripheral perfusion, and the patient died 8 days later.

Post-mortem examination demonstrated gross right ventricular hypertrophy, and hepatic congestion. There was neither macroscopic nor histological evidence of pulmonary embolism or infarction. Intimal proliferation and laminar fibrosis with areas of fibrinoid necrosis were seen in the pulmonary arterioles.

\section{Discussion}

While the prognosis of patients with primary pulmonary hypertension has generally been poor in the past (Sleeper, Orgain and McIntosh, 1962), recent studies of the vasodilator drugs such as hydrallazine (Rubin and Peter, 1980), phentolamine (Ruskin and Hutter, 1979) and diazoxide (Wang et al., 1978), raise hopes that the course of the disease may be significantly altered (Reeves, 1980).

A number of studies suggested that captopril and other angiotensin-converting-enzyme inhibitors might be particularly effective in reducing elevated pulmonary vascular resistance. Teprotide (SQ 20,881 ), a related drug, has been shown to produce a fall in pulmonary vascular resistance which is more marked than its effects on systemic vascular resistance in patients with hypertension (Niarchos, Roberts and Laragh, 1979) and congestive cardiac failure (Curtiss et al., 1978). Whether this effect is primarily due to inhibition of angiotensin II formation, decreased inactivation of plasma kinins, or secondary changes in the formation of vasodilator prostaglandins and prostacyclin, remains to be determined.
The present report is the first one of the use of captopril for this clinical condition. The patient was unfortunately in a moribund state at the start of the study, with clinical evidence of gross right heart failure associated with gross depression of cardiac output. Captopril was made available on the condition that the patient be pre-treated with indomethacin, because of fears of a possible bronchoconstrictor effect mediated by kinin and prostaglandin release (Greenberg et al., 1979). However, it is also possible that the pulmonary vasodilator effects of captopril which might be mediated by prostacyclin release, were significantly attentuated by indomethacin (Murthy, Waldron and Goldberg, 1978).

Acute administration of a very small dose of captopril was associated with a rise in cardiac output, and a fall in both pulmonary and systemic vascular resistance. Prolonged oral administration of captopril induced minor reduction in dyspnoea and improvement in hypoxaemia. However, these limited results suggest that further investigation of the effects of captopril in patients with primary pulmonary hypertension appears to be justified.

\section{Acknowledgments}

We would like to thank Dr J. Carson of E. R. Squibb< (Australia) for arranging the availability of captopril, anf Dr G. Dusting for his helpful comments.

\section{References}

Curtiss, C., Cohn, J.N., Vrobel, T. \& Franciosa, J.A: (1978) Role of the reinin-angiotensin system in the systemic vasoconstriction of chronic congestic heart failure. Circulation, 58, 763.

Greenberg, R., Osman, G.H., O'Keefe, E.H. \& AntonaCCIO, M.J. (1979) The effects of Captopril (SQ 14,225) on bradykinin-induced bronchoconstriction in the anaesthetized guinea-pig. European Journal of Pharmacology, 57, 287.

Murthy, V.S., Waldron, T.L. \& Goldberg, M.E. (1978) The mechanism of bradykinin potentiation after inhibition of angiotensin-converting enzyme of SQ 14,225 in conscious rabbits. Circulation Research, 43 (Suppl. 1), 40.

Niarchos, A.P., Roberts, A.J. \& LaRaGH, J.H. (1979) Effects of the converting enzyme inhibitor (SQ 20,881) on the pulmonary circulation in man. American Journal of Medicine, 67, 785.

ReEves, J.A. (1980) Hope in primary pulmonary hypertension? New England Journal of Medicine, 302, 112.

RUbiN, L.J. \& PeTer, R.H. (1980) Oral hydrallazine therapy for primary pulmonary hypertension. New England Journal of Medicine, 302, 69.

Ruskin, J.N. \& Hutter Jr, A.M. (1979) Primary pulmonary hypertension treated with oral phentolamine. Annals of Internal Medicine, 90, 772.

Sleeper, J.C., Orgain, E.S. \& McIntosh, H.D. (1962) Primary pulmonary hypertension: Review of clinical features and pathological physiology, with a report of pulmonary hemodynamics derived from repeated catheterization. Circulation, 26, 1358.

Wang, S.W.S., PoHL, J.E.F., Rowlands, D.J. \& Wade, E.G. (1978) Diazoxide in treatment of primary pulmonary hypertension. British Heart Journal, 40, 572. 